\title{
2'-Deoxyadenosine and A23187 as Agents for Inducing Synchrony in the Budding Yeast, Kluyveromyces fragilis
}

\author{
By C. S. PENMAN AND J. H. DUFFUS \\ Department of Brewing and Biological Sciences, Heriot-Watt University, \\ Edinburgh $E H \mathrm{I}$ I $H X$
}

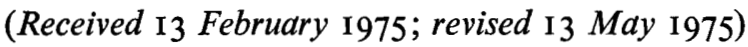

\begin{abstract}
SUMMARY
The effects of induction synchrony by 2'-deoxyadenosine and the ionophore A23 I 87 were compared with selection synchrony methods in Kluyveromyces fragilis. 2 -Deoxyadenosine synchronizes nuclear division and this is followed by synchronous cell division, but DNA synthesis is not synchronized. The ionophore A23187 also induces synchronous nuclear division and synchronous cell division, but likewise does not synchronize DNA synthesis.
\end{abstract}

\section{INTRODUCTION}

Over the past few years, two main methods have been used to produce synchronous cultures of yeast. The older method, developed by Mitchison \& Vincent (I965), involves centrifuging yeast cells through a sucrose gradient, removing cells from specific points in the gradient, and using these to initiate new cultures. This method gives a low yield, as most cells of the original culture are discarded, but it does not appear to distort the biosynthetic pathways of the cells. The newer method is to induce synchrony in yeast cultures using a metabolic inhibitor. Cultures of the fission yeast Schizosaccharomyces pombe may be induced using 2 mM-2'-deoxyadenosine (Mitchison \& Creanor, 197I). However, this method has been shown to produce distortions in the cell cycles of the resulting cultures (Sissons, Mitchison \& Creanor, I973).

This paper describes the use of two compounds, 2'-deoxyadenosine and A23187, as induction agents and their effects on the cell cycle of the budding yeast Kluyveromyces fragilis.

\section{METHODS}

Organism and cultural conditions. Kluyveromyces fragilis (NCYCIOo) was grown in Oxoid malt extract broth (MEB; $2 \%$, w/v) at $30{ }^{\circ} \mathrm{C}$ with shaking at 160 orbits $/ \mathrm{min}$. Under these conditions, the organism had a doubling time of $90 \mathrm{~min}$. Cell counts were carried out on one-drop samples using a Thoma haemocytometer. Yeast cells were taken to have divided once the bud was two-thirds the size of the mother cell (Duffus \& Penman, 1973).

The ionophore A23187 was a generous gift from Eli Lilly Ltd. Selection cultures were prepared by the method of Mitchison \& Vincent (1965), using the cells from $250 \mathrm{ml}$ asynchronous cultures harvested in mid-exponential growth phase. Induction cultures were established using either 2'-deoxyadenosine (AdR) or A23187. Induction with AdR was accomplished by adding the compound to an exponentially-growing culture of yeast to a final concentration of $2 \mathrm{mM}$. The blockade was applied for a period of $2 \mathrm{~h}$, after which the cells were harvested by centrifugation and re-inoculated into fresh MEB. 
For induction with A23I87, a stock solution of the compound was prepared by dissolving $6 \mathrm{mg}$ of it in $0.6 \mathrm{ml}$ Analar grade acetone and adding $10.0 \mathrm{ml} 100 \%(\mathrm{v} / \mathrm{v})$ ethanol. One $\mathrm{ml}$ of this stock solution was added to every $100 \mathrm{ml}$ exponentially-growing yeast culture, giving a final concentration of $0.011 \mathrm{mM}$.

Both means of induction produce cultures in which one can study 2 to 3 cycles before loss of synchrony occurs.

Estimation of nucleic acids. Samples were removed from cultures synchronized with both AdR and A23 187 during and following the pulse periods. The cells from these samples were harvested by centrifugation. DNA was estimated following Bostock (1970). Portions $(0.1 \mathrm{ml})$ of the perchloric acid extracts were diluted to $2.0 \mathrm{ml}$ with distilled water and RNA determined using the method of Mejbaum (1939).

Protein estimation. The pellets remaining after nucleic acid estimation were hydrolysed in $5 \mathrm{ml}$ portions of $\mathrm{I} \mathrm{M}-\mathrm{NaOH}$ at $60^{\circ} \mathrm{C}$ for $\mathrm{I} \mathrm{h}$. Portions $(0 . \mathrm{I} \mathrm{ml})$ of the alkaline hydrolysates were made up to $2.0 \mathrm{ml}$ with distilled water and protein determined with the Miller (I959) modification of the method of Lowry et al. (I95I), using bovine serum albumin fraction $\mathrm{V}$ as a standard.

Determination of the time of nuclear division. Samples from cultures induced with AdR and $\mathrm{A}_{23} \mathrm{I}_{7} 7$ were removed at various times, fixed, and stained as described previously (Duffus \& Penman, 1973). The stained slides were observed, the percentage of binucleate cells counted, and the time of nuclear division determined.

Determination of dry mass increase. Small samples $(3 \mathrm{ml})$ were removed before, during, and after inhibitor treatment. The absorption of each sample was measured at $595 \mathrm{~nm}$ against MEB blank. The increase in absorption is roughly proportional to total dry mass increase (Mitchison \& Creanor, 197I).

\section{RESULTS}

Figure I shows the pattern of DNA synthesis in a synchronous culture prepared by gradient selection. DNA doubled at the same time in each cell cycle. Graphically, the points for DNA doubling and cell division appear to be the same since the period of DNA synthesis (S) in this yeast is too close to the time of cell division to be clearly distinguished.

Figure 2 shows the pattern of DNA accumulation during an AdR blockade and following transfer from the AdR medium to normal medium. When AdR was applied to a culture of $K$. fragilis in exponential growth, DNA synthesis continued exponentially for $120 \mathrm{~min}$, after which time the total cell DNA began to level off. This levelling off of DNA was accom-
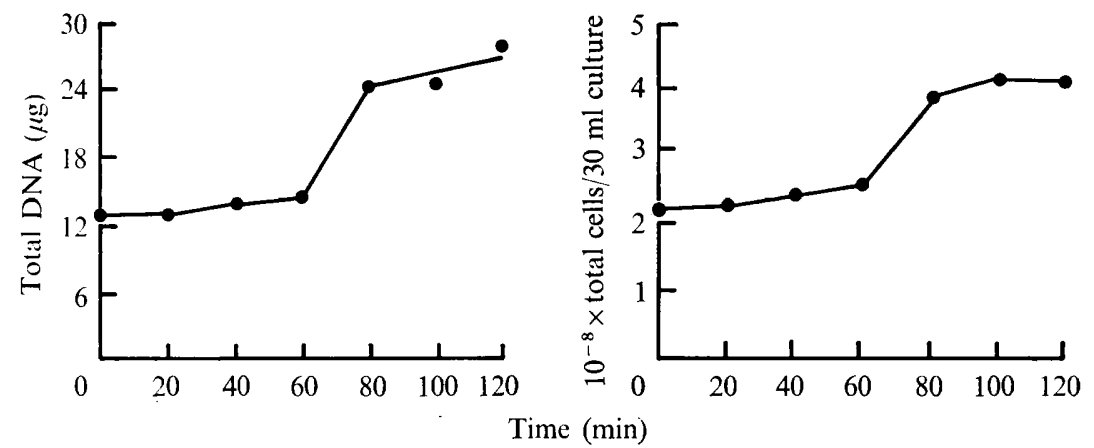

Fig. I. Bulk changes in total DNA in MEB synchronous cultures of $K$. fragilis prepared by selection and growing at $30^{\circ} \mathrm{C}$. 
panied by a corresponding plateau of cell numbers. Following transfer to normal medium, accumulation of DNA was found to be exponential with a doubling time of $60 \mathrm{~min}$. The effect of the inhibitor on cell division is also shown in this graph. Before the first synchronous division there was a lag period lasting $70 \mathrm{~min}$. This division was followed by a much shortened cycle lasting just $60 \mathrm{~min}$, after which there was another cell division followed by a cycle lasting 100 min (not shown in Fig. 2).

When AdR was added to exponentially-growing asynchronous cultures, the overall growth in mass, as determined by absorption measurements, appeared to continue normally. Following re-inoculation into fresh MEB, cells treated with AdR showed an increase in overall cell mass which was a little slower than that occurring during treatment. RNA and protein synthesis were unaffected by AdR during a pulse period lasting I40 min and continued normally following re-inoculation.

When A23187 was added to growing cultures of $K$. fragilis, the cell mass began to level off after I ro min, as did DNA and protein synthesis. Following the release of the blockade,
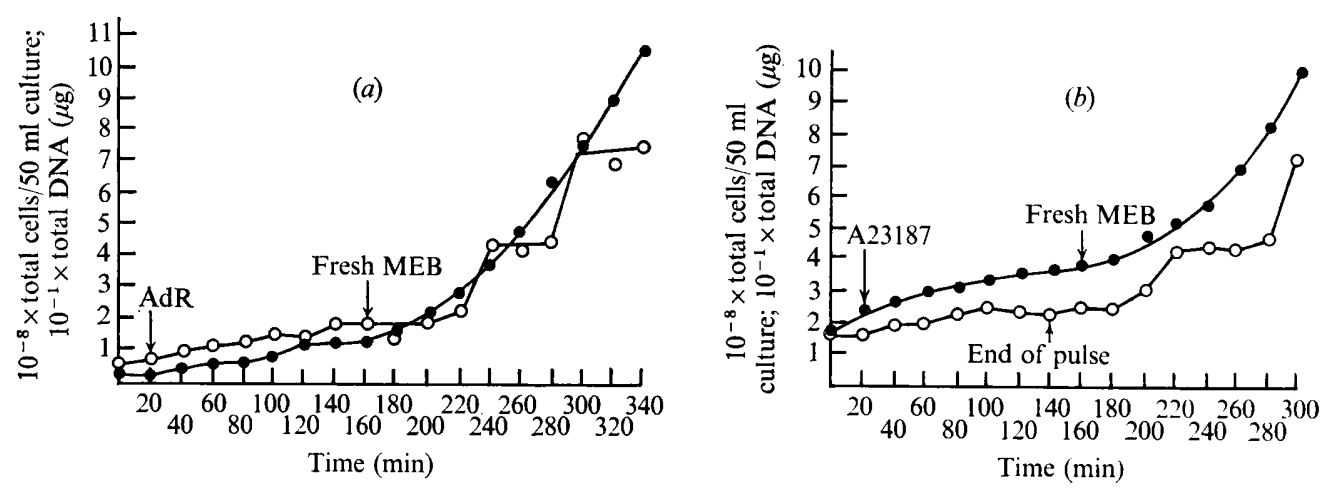

Fig. 2. Bulk changes in total DNA in $K$. fragilis growing in MEB at $30^{\circ} \mathrm{C}$ during and following (a) a 2 mM-AdR block and (b) a 0.0 I I mM-A23187 block. 0 , DNA; $O$, cells.

Table I. The percentage of binucleate cells, determined by Giemsa staining, in samples from cultures of $K$. fragilis in MEB synchronized by AdR and A23187

\begin{tabular}{|c|c|c|c|c|c|}
\hline $\begin{array}{l}\text { Treatment } \\
\text { AdR }\end{array}$ & $\begin{array}{l}\text { Time** } \\
\text { (min) }\end{array}$ & $\begin{array}{l}\text { Percentage of } \\
\text { binucleate } \\
\text { cells }\end{array}$ & $\begin{array}{c}\text { Treatment } \\
\text { A23187 }\end{array}$ & $\begin{array}{l}\text { Time* } \\
\text { (min) }\end{array}$ & $\begin{array}{l}\text { percentage of } \\
\text { binucleate } \\
\text { cells }\end{array}$ \\
\hline & 0 & 3.55 & & 0 & $5 \cdot 30$ \\
\hline & 20 & 3.85 & & 20 & 4.45 \\
\hline & 40 & 9.00 & & 40 & 10.03 \\
\hline & $60 t$ & $2 \cdot 50$ & & $60 \dagger$ & $6 \cdot 26$ \\
\hline & 80 & $3 \cdot 30$ & & 80 & 5.08 \\
\hline & 100 & $3 \cdot 10$ & & 100 & $4 \cdot 84$ \\
\hline
\end{tabular}

the overall cell mass increased at a slower rate than during treatment, DNA synthesis restarted immediately, and, as was the case with treatment using AdR, this increase was not synchronous. However, unlike the situation following treatment with AdR, DNA doubled in $80 \mathrm{~min}$, or very nearly the time of a normal cycle. This corresponds to the cycle time following re-inoculation, which was also 80 minutes. Cultures induced with A23I87 contained cells in which the nuclei were elongated and pinched, as judged by light microscopy 
and Giemsa staining, as though the nuclei were arrested at some stage in mitosis. AdR on the other hand did not cause such effects on nuclei.

Table I shows the results of Giemsa staining on samples from synchronous cultures induced with AdR or A23187, and the percentages of binucleate cells. After treatment with either inhibitor, nuclear division occurred about $40 \mathrm{~min}$ after re-inoculation.

\section{DISCUSSION}

The degree of synchrony obtained by both the techniques described here is very high. It can be seen best in the AdR cultures where all the cells divide within $20 \mathrm{~min}$ in three successive divisions. This represents approximately 0.2 of the cell cycle of this organism, so that, when compared with other cells, it is not as spectacular as it appears.

When AdR was applied to growing cultures of Schizosaccharomyces pombe, there was no inhibition of DNA synthesis for 40 to 60 min (Mitchison \& Creanor, 197I). Treatment of $K$. fragilis cells produced a much longer lag (I $20 \mathrm{~min}$ ) before DNA synthesis began to decline. There was no corresponding inhibition of either RNA or protein accumulation, a pattern also observed by Mitchison \& Creanor (197I). These workers further observed that extinction measurements on culture samples, which are roughly proportional to total dry mass determinations, continued to increase unaffected by AdR, resulting in abnormally large cells of the fission yeast. Extinction measurements of $K$. fragilis cultures also showed this picture.

AdR brings about synchronous nuclear division though DNA synthesis is not synchronized. The shortened cycle time resulting from AdR treatment suggests that the cells are attempting to restore their normal size and also maintain their correct complement of DNA in the face of accelerated DNA synthesis. The lack of synchrony of DNA synthesis makes it unlikely that AdR induces synchronous division as a result of an effect on DNA synthesis (Mitchison \& Creanor, 197I). This inhibitor may reduce the level of ATP within the cells by competitive inhibitory effects on the ATP synthesizing systems or by the formation of biologically inactive deoxy-ATP (S. Shall, personal communication). Since mitosis is a fairly energy-demanding process (Mazia, 1963), there would be insufficient energy for this process to be carried out; hence nuclear division would be synchronized, resulting in synchronous cell division on the release of the block. Support for this hypothesis comes from observations made by J. H. Duffus and L. J. Paterson in this laboratory, who found that 2 mM-AdR inhibition may be rapidly reversed by the addition of ATP, GTP or ADP, or, slightly more slowly, by AMP or adenine at equimolar concentration. The observations by Mitchison \& Creanor (I97I) that fission yeast cells can recover spontaneously from the effects of AdR may be accounted for by the cells' ability to synthesize ATP directly from deoxy-ATP.

A23 187 is a carboxylic acid antibiotic with a molecular weight of 523 and an elemental analysis of $\mathrm{C}_{29} \mathrm{H}_{13} \mathrm{O}_{6} \mathrm{~N}_{3}$ (Reed \& Lardy, 1972). It binds divalent, but not monovalent, cations at $\mathrm{pH} 7.4$. It alters the magnesium and calcium levels of rat liver mitochondria, apparently as a result of its ability to enter mitochondrial membranes and act as a freely mobile carrier to equilibrate divalent cation concentrations across these membranes (Reed \& Lardy, I972). Duffus \& Paterson (I974) used this compound to induce synchronous cell division in $S$. pombe. When added to cultures of $K$. fragilis, there is a levelling off of the overall cell growth. DNA and protein accumulation are arrested after I Io min of treatment. Following re-inoculation into fresh MEB, the increase in cell mass is much slower than during the treatment period. Results from Giemsa staining suggest that cells are arrested at a 
stage during mitosis which results in synchronous nuclear division, although DNA synthesis is not synchronized. Duffus \& Paterson (1974) concluded that a pool of magnesium and calcium ions is necessary for cell division to take place. They have suggested that this pool is necessary for the breakdown of microtubules involved in mitosis (and, in the case of $S$. pombe, also in cell plate formation). Such a mechanism in $K$. fragilis would account for the large number of elongated nuclei seen following Giemsa staining.

A23187, like AdR, induces synchronous cell division in $K$. fragilis and dissociates the DNA synthetic cycle from the growth/division cycle. However, it produces synchronous cultures which may be less abnormal than those resulting from AdR treatment, since there is no shortened cycle and DNA doubles over a period of $80 \mathrm{~min}$, or very nearly the normal time.

The two inhibitors may act through fundamentally the same system; the availability of ATP may be the key to both. A23187 has been shown to uncouple oxidative phosphorylation in rat liver mitochondria, in magnesium-free medium (Reed \& Lardy, 1972), and dramatically to lower cell magnesium levels (Pressman, I973; Duffus \& Paterson, 1974) affecting ATP utilizing and synthesizing systems.

The inhibitors used have synchronized nuclear and cell division, while DNA synthesis continued in an essentially asynchronous fashion. This may mean either that the $S$ period was occurring randomly in individual cells in the synchronous culture, or that DNA synthesis was occurring very slowly in all cells so that the $S$ period was extended to fill the whole cycle from nuclear division to nuclear division. In either event, it would appear that the use of the $S$ period as an important reference point in mapping the cell cycle is not practicable in such cultures.

We thank the SRC for a research studentship for C.S.P. tenable during the course of this work and for grant No. B/RG/06526 to J.H.D. We are also grateful to Professor D. J. Manners for providing postdoctoral support for C.S.P.

\section{REFERENCES}

Bostock, C. J. (1970). DNA synthesis in the fission yeast, Schizosaccharomyces pombe. Experimental Cell Research 60, 16-26.

Duffus, J. H. \& PAterson, L. J. (1974). Control of cell division in yeast using the ionophore, A23187, with calcium and magnesium. Nature, London 251, 626-627.

Duffus, J. H. \& Penman, C. S. (1973). Stepwise accumulation of an acid-extractable protein fraction in the budding yeast, Kluyveromyces fragilis, during the cell cycle. Journal of General Microbiology 79, I 89-194.

Lowry, O. H., Rosebrough, N. J., FarR, A. L. \& Randall, R. J. (195I). Protein measurement with the Folin phenol reagent. Journal of Biological Chemistry 193, 265-275.

MAZIA, D. (I963). Synthetic activities leading to mitosis. Journal of Cellular and Comparative Physiology 62, SI, I 23-I 40 .

Mejbaum, W. (1939). Estimation of small amounts of pentose, especially in derivatives of adenylic acid. Hoppe-Seyler's Zeitschrift für physiologische Chemie 258, I17-1 20.

Miller, G. L. (1959). Protein determination for large numbers of samples. Analytical Chemistry 31, 964.

Mitchison, J. M. \& Creanor, J. (1971). Induction synchrony in the fission yeast, Schizosaccharomyces pombe. Experimental Cell Research 67, 368-374.

Mitchison, J. M. \& VINCENT, W. S. (1965). Preparation of synchronous cell cultures by sedimentation. Nature, London 205, 987-989.

Pressman, B. C. (1973). Properties of ionophores with broad range cation selectivity. Federation Proceedings 32, 1698-1703.

ReED, P. W. \& LARDY, H. A. (1972). A23187: a cation ionophore. Journal of Biological Chemistry 247, 6970-6977.

Sissons, C. H., Mitchison, J. M. \& Creanor, J. (1973). Enzyme synthesis and potential during induction synchrony in the fission yeast, Schizosaccharomyces pombe. Experimental Cell Research 82, 63-72. 